\title{
Могорычев А.М.
}

Сущность и предмет прокурорского надзора за исполнением законов о разрешительной системе. Проблемы их определения в Республике Крым

Прокуратура Республики Крым

(Россия, Симферополь)

doi: 10.18411/lj-08-2021-135

\section{Аннотация}

В данной работе автором определены проблемные аспекты при установлении предмета прокурорского надзора за исполнением законов о разрешительной системе. Делается вывод о том, что предмет прокурорского надзора за исполнением законов, сформулированный в ст. 21 ФЗ «О прокуратуре РФ», определен не точно, что приводит к расширительному толкованию данной нормы прокурорами, необоснованному превышению прокурорами предоставленных полномочий. В связи с отмеченным автором делается вывод о необходимости внесения изменений в действующее законодательство, определив на уровне федерального законодательства исчерпывающий список нормативных источников, составляющих предмет прокурорского надзора за исполнением законов о разрешительной системе, расположив их в порядке убывания юридической силы.

Ключевые слова: Российская Федерация, прокурорский надзор, разрешительная система, национальная безопасность, акт, исполнение, прокуратура, свобода человека, правовое регулирование, соблюдение Конституции.

\section{Abstract}

In this publication, the author identifies problematic aspects when establishing the subject of prosecutor's supervision over the implementation of laws on the licensing system. It is concluded that the subject of prosecutor's supervision over the execution of laws, formulated in Article 21 of the Federal Law "On the Prosecutor's Office of the Russian Federation", is not precisely defined, which leads to an expansive interpretation of this norm by prosecutors, an unjustified excess of the powers granted by prosecutors. In connection with the above, the author concludes that it is necessary to amend the current legislation by defining at the level of federal legislation an exhaustive list of regulatory sources that constitute the subject of prosecutor's supervision over the implementation of laws on the licensing system, placing them in descending order of legal force.

Keywords: Russian Federation, prosecutor's supervision, licensing system, national security, act, execution, prosecutor's office, human freedom, legal regulation, compliance with the Constitution.

На сегодняшний день разрешительную систему можно охарактеризовать как некий сложно организованный механизм, состоящий из разветвленной системы контролирующих органов, целью которых является воздействие на субъектов определенных правоотношений. В адрес органов, представляющих разрешительную систему, каждый год подается огромное количество обращений, по результатам которых назначаются и проводятся проверки. Однако законодательство Российской Федерации, регламентирующее разрешительную систему, имеет определенные недостатки, связанные с его коллизионностью, частыми внесениями изменений. Эта проблема для Республики Крым увеличивается за счет положения Федерального конституционного закона от 21.03.2014 № 6-ФКЗ «О принятии в Российскую Федерацию Республики Крым и образовании в составе Российской Федерации новых субъектов - Республики Крым и города федерального значения Севастополя» о том, что на территориях Республики Крым и города федерального значения Севастополя 
действуют документы, в том числе разрешительные документы (лицензии, кроме лицензий на осуществление банковских операций и лицензий (разрешений) на осуществление деятельности некредитных финансовых организаций), выданные государственными и иными официальными органами Украины, государственными и иными официальными органами Автономной Республики Крым, государственными и иными официальными органами города Севастополя, без ограничения срока их действия и какого-либо подтверждения со стороны государственных органов Российской Федерации, государственных органов Республики Крым или государственных органов города федерального значения Севастополя, кроме некоторых исключении, предусмотренных статьей 12.2 Федерального конституционного закона № 6-ФКЗ, а также если иное не вытекает из самих документов или существа отношения. Поэтому разрешительная система в настоящее время в Республике Крым не урегулирована надлежащим образом, а это соответственно приводит к неизбежным нарушениям прав и свобод человека и гражданина, так как разрешительная деятельность связана с самыми опасными сферами жизнедеятельности общества.

Главным теоретическим и практическим аспектом, который позволит благотворно повлиять на эту ситуацию является установление предмета прокурорского надзора за исполнением законодательства о разрешительной системе.

Сущность прокурорского надзора в исследуемой сфере состоит в надзоре за соответствием действий или бездействий поднадзорных органов и лиц, издаваемых ими актов, положениям действующего законодательства Российской Федерации. Для правильного установления предмета прокурорского надзора за разрешительной сферой представляется необходимым охарактеризовать нормативно-правовую основу, регламентирующую эту сферу.

В ст. 21 Федерального закона «О прокуратуре Российской Федерации» указано, что предмет прокурорского надзора определяется такими составляющими, как соблюдением Конституции Российской Федерации, исполнением законов и как формой первых двух - соответствием законам правовых актов.

Актуализируются и имеют проблемные моменты вопросы, связанные с обеспечением соответствия всех нормативных правовых актов конституционным положениям. По своей юридической силе Конституция РФ занимает главное место в иерархии нормативных правовых актов Российской Федерации. Грань между Конституцией РФ и иными законодательными актами на сегодняшний день очень тонкая, нечеткая и нерегламентированная, что негативным образом сказывается на реализации и воплощении в жизнь конституционных положений. Подобное также нивелирует задекларированные в Основном законе РФ догмы о том, что Российская Федерация - правовое, демократическое государство.

В федеральных законах, а также организационно-правовых документах, издаваемых Генеральным прокурором РФ, устанавливается правило о необходимости достижения соответствия конституционным положениям всех принимаемых нормативных актов на территории Российской Федерации, что реализуется с использованием всех средств прокурорского реагирования.

Обращаясь к положениям п. 1 ст. 21 ФЗ «О прокуратуре РФ», представляется возможным указать на существующее противоречие уже в рамках самой законодательной нормы. Пункт 1 ст. 21 Ф3 «О прокуратуре РФ» предполагает возможность надзора только за соответствием законам издаваемых поднадзорными объектами (органами и должностными лицами) правовых актов. Следовательно, если предметом надзора в общем представляет собой соблюдение Конституции Российской Федерации и исполнение законов поднадзорными объектами, то надзор за законностью правовых актов ограничен лишь сферой исполнения законов. 
Представляется необходимым внесение изменений в данную законодательную норму, а именно, дополнить указанием на соответствие конституционным положениям всех нормативных актов, которые были изданы органами и должностными лицами, поднадзорными прокуратуре.

Предмет прокурорского надзора в исследуемой сфере в Республике Крыму также имеет свою специфику. Перед разрешительной системой в целом законодателем определены и закреплены на нормативном уровне цели, предполагающие всестороннее обеспечение прав и свобод человека и гражданина, общественных и государственных интересов. Исходя из таких глобальных целевых установок, возложенных для реализации на разрешительную систему, можно утверждать о том, что прокурорский надзор за исполнением законодательства в данной сфере можно охарактеризовать как такой, который направлен на обеспечение национальной безопасности.

Прокуратура осуществляет надзор за исполнением законов о разрешительной системе в деятельности других поднадзорных ей субъектов, при этом сама относится к правоохранительным органам и занимает особое место в системе органов, на которых возложено обеспечение национальной безопасности. Согласно утверждаемым Президентом РФ Стратегиям национальной безопасности, прокурорский надзор за исполнением законодательства о разрешительной системе всеми поднадзорными прокуратуре субъектами выступает одним из важных и приоритетных направлений, нацеленных на реализацию и воплощение в жизнь в целом безопасности российского государства и общества.

В настоящее время в обеспечении национальной безопасности большая роль отводится именно направлению нормативного ее обеспечения. Для этого действующее законодательство оптимизируется, усовершенствуется, создавая необходимые предпосылки для эффективной прокурорской деятельности по обеспечению национальной безопасности, в том числе и в сфере разрешительной деятельности. Отмеченное позволит в числе всего укрепить состояние законности в разрешительной системе.

Определяя предмет прокурорского надзора за исполнением законов, законодатель не относит к нему надзор за исполнением подзаконных актов. Но в научных трудах, а также в правоприменительной практике часто указывают на тот факт, что подзаконные нормативные правовые акты относятся к предмету прокурорского надзора за исполнением законов. При этом следует не забывать о том, что ст. 21 Ф3 «О прокуратуре РФ» не подлежит расширительному толкованию, и поскольку законодатель не указал на данные нормативные источники в числе предмета прокурорского надзора, то это недопустимо. Все формы нормативных правовых источников официально поименованы, закреплены на уровне Основного закона РФ, и какое-либо отступление от этого закрытого, исчерпывающего перечня недопустимо. Подобное позволит нарушить стабильность, имеющуюся в правопорядке и состоянию законности в государстве.

Поэтому не стоит расширять тот смысл, который вложен законодателем в содержание ст. 21 Ф3 «О прокуратуре РФ». Если отождествлять употребляемое в данной статье слово «закон» с понятием «законодательство», то будут нарушены рамки общего надзора, что в целом приведен к отсутствию эффективности в деятельности прокуратуры. При расширительном толковании отмеченной статьи Ф3 «О прокуратуре РФ» также не исключается наличие коррупционных факторов, необоснованное и незаконное расширение полномочий прокурора, что может также и дезориентировать его и неумышленно выходить за пределы той компетенции, которая ему предоставлена.

Таким образом, представляется необходимым устранить законодательную коллизию в рамках ст. 21 Ф3 «О прокуратуре РФ», в которой определен предмет 
прокурорского надзора за исполнением законов, в том числе и законодательства о разрешительной системе. Следовательно, ст. 21 Ф3 «О прокуратуре РФ» подлежит изложению в новой редакции с учетом изменений, необходимых для конкретизации предмета прокурорского надзора.

Что касается того, каким же именно образом необходимо изложить в новой редакции ст. 21 ФЗ «О прокуратуре РФ», то в научно-исследовательских трудах высказываются различные точки зрения.

Для того, чтобы существенно повысить уровень эффективности деятельности прокуратуры по надзору за исполнением законов, следует искоренить двойные стандарты, имеющие место при определении предмета прокурорского надзора. Это возможно при определении предмета прокурорского надзора в отдельных приказах, издаваемых Генеральным прокурором РФ. В таком организационно-правовом акте можно перечислить определенный круг нормативно-правовых актов, которые относятся к предмету прокурорского надзора. Также в подобных приказах Генерального прокурора РФ следует закреплять и рекомендации о том, какие именно акты необходимо относить к прокурорскому надзору, в частности, подзаконных нормативных правовых актов, издаваемых Президентом РФ, Правительством РФ, министерствами.

Представляется, что наиболее целесообразно будет внести изменения в Ф3 «О прокуратуре РФ», указав в нем исчерпывающим способом все нормативно-правовые акты, расположив их по мере убывания юридической силы, относящиеся к предмету прокурорского надзора за исполнением законов. А, в случае с феноменом правового регулирования в Республике Крым, указать в примечании возможные нормы пролонгированного действия.

Прокуратура как правоохранительный орган призвана обеспечивать стабильность и устойчивость законодательства, принимаемого на территории Российской Федерации, используя при этом весь арсенал правовых средств, относящихся к ее компетенции.

Основываясь на вышеизложенном, представляется необходимым сформулировать дефиницию предмета прокурорского надзора за исполнением законов о разрешительной системе. Так, предмет прокурорского надзора за исполнением законов о разрешительной системе - это исполнение законов, регламентирующих порядок предоставления компетентными органами разрешений, реализации форм разрешительной деятельности, осуществление государственного контроля (надзора) за деятельностью, действиями, бездействиями, издаваемыми правовым актами поднадзорными прокуратуре органами и должностными лицами.

$$
* * *
$$

1. Федеральный закон от 17.01.1992 № 2202-1 «О прокуратуре Российской Федерации» // Собрание законодательства РФ, 20.11.1995, № 47, ст. 4472.

2. Васильев Ф.П., Дугенец А.С. Осуществление государственных надзорно-контрольных функций в России и их научно-теоретическое толкование в административном праве на современном этапе // Вестник Московского университета МВД России. - 2014. - № 5. - С. 146-153.

3. Майоров А.В., Литовченко С.А. Теоретические основы прокурорского надзора за исполнением законов // Вестник Челябинского государственного университета. - 2020. - № 5. - С. 49-54.

4. Субанова Н.В. Теоретические и прикладные основы прокурорского надзора за исполнением законов о разрешительной системе: автореф. дис. ... к.ю.н., спец. 12.00.11. - Москва, 2014. - 28 с.

5. Торопин Ю.В., Васильев Ф.П. Административно-правовое регулирование обеспечения экономической безопасности России // Труды Академии управления МВД России. - 2014. - № 2 (30). - C. 67-71.

6. Шалумов М.С. Прокурорский надзор и государственный контроль за исполнением законов: разграничение компетенции и ответственности // Государство и право. $-1999 .-$ № 1. - С. 81-88. 